\title{
The Concept of Mental Disease in Criminal Law Insanity Tests
}

\author{
Herbert Fingarette
}

\begin{abstract}
This critique and its proposals focus upon the concept of mental disease ${ }^{1}$ in insanity tests in contemporary American criminal law and specifically upon those tests relating to the culpability of the accused ${ }^{2}$ rather than to his capacity to stand trial or to face execution. ${ }^{3}$ Although there are,
\end{abstract}

Herbert Fingarette is Professor of Philosophy, University of California, Santa Barbara. He received his B.A. and Ph.D. degrees from the University of California, Los Angeles, in 1947 and 1949 respectively.

$I$ "Mental disease" is often interchanged with such synonymous variants as "disease of the mind," "mental illness," "mental disorder," and "unsound mind." See, e.g., Carter v. United States, 252 F.2d 608, 617 (D.C. Cir. 1957) ("Mental "disease' means mental illness."); Durham v. United States, 214 F.2d 862, 876 (D.C. Cir. 1954) ("mental disease" and "mental disorder" used in a way clearly implying their equivalence).

This article does not deal with the special problems of organic mental disease-those which are manifested in tissue change or abnormality-but deals rather with those general abnormalities classified as "behavioral." A thorough analysis of the legal effect of organic defects and a substantial bibliography, mostly of medical sources, may be found in Fox, Physical Disorder, Consciousness, and Criminal Liability, 63 Colum. L. REv, 645 (1963).

Nor does this article deal with the other elements of the criminal law insanity tests"knowing the nature and quality of the act," "knowing the act is wrong," "irresistible impulse," or "incapacity to conform to law or to appreciate the criminality of the act."

2 In addition to the M'Naghten, Durham, and Model Penal Code tests, set out in notes 7,9 , and 10 infra, respectively, current criminal law insanity tests include the following: (1) "The jury must be satisfied that at the time of committing the prohibited act the defendant, as a result of mental disease or defect, lacked substantial capacity to conform his conduct to the requirements of the law he is alleged to have violated." United States v. Currens, 290 F.2d 751, 774 (3d Cir. 1961). (2) "[W]hether there is such a mental disease as dipsomania, and whether defendant had that disease, and whether the killing of [the victim] . . . was the product of such disease, were questions of fact for the jury." State v. Pike, 49 N.H. 399, 407-08 (1869). See also State v. Jones, 50 N.H. 369, 398 (1871). (3) The Royal Commission on Capital Punishment, 1949-1953 Report, CMid. No. 8932 , at 116, 276 (1953), recommended abrogating M'Naghten and leaving "the jury to determine whether at the time of the act the accused was suffering from disease of the mind (or mental deficiency) to such a degree that he ought not to be held responsible."

3 The standard test as to ability to stand trial relates to the capacity of the accused to understand the proceedings against him or to assist in his own defense. See, e.g., ModEL Penal CoDe \& 4.04 (Proposed Final Draft No. 1, 1961). The special problems of intervening insanity prior to execution are discussed in Ehrenzweig, $A$ Psychoanalysis of the Insanity Plea-Clues to the Problems of Criminal Responsibility and Insanity in the Death Cell, 73 YALE L.J. 425 (1964). 
in this area, crucial problems of a logical or conceptual kind amenable to philosophical analysis, the literature is almost entirely the work of jurists, psychiatrists, and psychologists. ${ }^{4}$ This article attempts to fill that gap with a unified, concrete discussion in which legal, psychiatric, and philosophical analyses are intertwined.

The article consists of three major parts. The first will explore generally the need for proper definition and analysis of the concept of mental disease in criminal law insanity tests and will survey the relevant current literature to show that there is no medically or scientifically recognized concept of mental disease. The second part presents a conceptual analysis of the logical status and role of mental disease in the context of medicine and law. The final part of the discussion argues that there is a legitimate and necessary role for the notion "mental disease" as an element of a sound criminal law test for insanity, and offers concrete proposals for interpreting "mental disease" so that it can properly and clearly play this role. The analysis provides justification for maximal freedom for expert testimony in court and tends to encourage the use of this freedom; the analysis also results in disengaging legal doctrine from commitment to specific diagnoses, theories, doctrines, concepts, or other technical tenets peculiar to the state of psychiatry or psychology at a particular time.

\section{The Unsatisfied Need for a Definition of Mental Disease}

The criminal law in its concern for the responsibility of the actor has traditionally insisted on the existence of a "guilty mind"-mens reain order to hold an actor criminally responsible for his acts. Thus, insanity has emerged as a criminal law defense. ${ }^{5}$ Without paraphrasing the language of any of the various insanity tests, I think it can be

4 See generally Glueck, Law and Psychiatry (1962); Guttmacher \& Werhofen, Psychiatry and the Law (1952); Roche, The Criminal Mind (1958); Rubin, Psychlatry and Criminal Law (1965). There have been numerous recent evaluations of the various tests, especially stimulated, it seems, by the Durham opinion in 1954. See, e.g., Kuh, The Insanity Defense-An Effort To Combine Law and Reason, 110 U. PA. L. REv. 771 (1962); Reid, Criminal Insanity and Psychiatric Evidence: The Challenge of Blocker, 8 How. L.J. I (1962). Philosophical studies have been generally devoted to the various insanity tests themselves, not to the underlying problems raised by their terminology. See, e.g., Raab, A Moralist Looks at the Durham and M'Naghten Rules, 46 Mins. L. REv. 327 (1961). One article focuses on the concept of "mental disease" from the viewpoint of the drafter of legislation. See Swartz, "Mental Disease": The Groundwork for Legal Analysis and Legislative Action, 111 U. PA. L. REv. 389 (1963).

5 See, e.g., United States v. Currens, 290 F.2d 751, 773-76 (3d Gir. 1961); BigGs, ThE Guilty Mind: Psychiatry AND The LAW OF Homicide 35-118 (1955); Hall, Psychiatry and Criminal Responsibility, 65 YALE L.J. 761 (1956); Rome, McNaughten, Durham and Psychiatry, 34 F.R.D. 93, 95-105 (1964). 
generally agreed that insanity in the legal sense connotes the absence of a guilty mind and that the aims of punishment, especially deterrence and retribution, are not effected by imposing sanctions on insane persons. ${ }^{6}$ In determining whether a person was legally insane at the time of the criminal act, the concept of mental disease has been an important element since the M'Naghten rules $^{7}$ were formulated by the House of Lords over a century ago. ${ }^{8}$ And two modern insanity tests-those of Durham $^{9}$ and the Model Penal Code ${ }^{10}$-require that the criminal act be "the product of" or "result of" mental disease or defect, thus placing even greater emphasis on mental disease than does M'Naghten."11

Insanity has been used historically to denote those persons whose state has resulted from involuntary causes, and hence the analogy to physical disease was a natural one. ${ }^{12}$ We think of insane persons as

B Of course, any such summary must incur dangers of oversimplification, and this one is no exception. Some of the various problems and issues are posed in Guvecr, op. cit. supra note 4, at 5-19; HAll, General Principles of Criminal Law 477-538 (1947). A general and perhaps more traditional approach is presented by Michael, Psychiatry and the Criminal Law, 21 A.B.A.J. 271 (1935).

7 "[I]० establish a defence on the ground of insanity, it must be clearly proved that, at the time of the committing of the act, the party accused was labouring under such a defect of reason, from disease of the mind, as not to know the nature and quality of the act he was doing; or, if he did know it, that he did not know he was doing what was wrong." M'Naghten's Case, 10 Cl. \& F. 200, 210, 8 Eng. Rep. 718, 722 (H.L. 1843).

8 See, e.g., Durham v. United States, 214 F.2d 862, 876 (D.C. Cir. 1954); Watson, $A$ Critique of the Legal Approach to Crime and Correction, 23 LAW \& ConTEMr. ProB. 611, 618-22 (1958).

9 "[A]n accused is not criminally responsible if his unlawful act was the product of mental disease or mental defect." Durham v. United States, 214 F.2d 862, 875 (D.C. Cir. 1954).

10 Model Penal Code (Proposed Final Draft No. 1, 1961):

Section 4.01 Mental Disease or Defect Excluding Responsibility

(1) A person is not responsible for criminal conduct if at the time of such

conduct as a result of mental disease or defect he lacks substantial capacity either to appreciate the criminality [wrongfulness] of his conduct or to conform his conduct to the requirements of law.

(2) [T] he terms "mental disease or defect" do not include an abnormality

manifested only by repeated criminal or otherwise antisocial conduct.

11 While the phrase "disease of the mind" appears in M'Naghten, it has been generally considered that the test stresses the cognitive capacity of the defendant, particularly at the time of the act. Strictly speaking, it is not a "product" test-one engendering difficult problems of causality. See, e.g., Allen, The Rule of the American Law Institute's Model Penal Code, 45 MarQ. L. Rev. 494, 497-99 (1962); Kuh, supra note 4, at 781-85, 795. Of course, it has been noted that jurisdictions applying M'Naghten have tended to give wide latitude to psychiatric testimony, in effect allowing investigation similar to that under Durham or the Model Penal Code. See, e.g., Rubin, op. cit. supra note 4, at 7-10; Wertham, Psychoauthoritarianism and the Law, 22 U. CHr. L. REv. 396 (1955).

12 These points are much more fully developed in the third section of this article. They are presented here only to provide a logical perspective so that the importance of the term "mental disease" and its relation to criminal law may be appreciated. Certainly all commentators are not in agreement even as to these very general statements. However, they do appear to represent the majority view. See, e.g., Roche, op. cit. supra 
being afflicted (acted upon rather than acting)-as being "sick" through no fault of their own-and thus we do not hold them criminally responsible. It was perhaps inevitable under these circumstances that the term "mental disease" should have come to acquire its present importance in this area, but in several respects this development was unfortunate. The term was developed in the context of legal tests of criminal responsibility, but no legal definition evolved. Rather, since the courts and legislators were well aware of the analogy to physical disease, it was and has been generally assumed that "mental disease" is a medical term, ${ }^{13}$ more particularly a term within the special purview of those medical men charged with behavioral abnormalities-the psychiatrists.

Turning to the psychiatric literature to explore this general thesis reveals, however, that there is no authoritative or generally accepted medical definition of mental disease. Indeed, the single most impressive fact is a negative one: the phrase "mental disease" is notable by its absence in most of the vast theoretical, textbook, clinical, and dictionary literature. ${ }^{14}$ When the problem of defining mental disease is raised explicitly, it is resolved by psychiatric authorities in substantially the following very different ways: (I) There is no such medical entity as mental disease, or we would do well not to use the phrase. ${ }^{15}$

note 4, at 14-29; Swartz, supra note 4, at 398; Szasz, Psychiatry, Ethics and the Criminal Law, 58 Colum. L. REv. 183 (1958).

13 See, e.g., Carter v. United States, 252 F.2d 608, 617 (D.C. Cir. 1957) ("Mental illnesses ... are the subject matter of medical science."); Weihofen, The Definition of Mental Illness, 21 OHг ST. L.J. 1 (1960) ("Mental illness is a medical concept, and so it would seem self-evident that its definition should come from the medical profession and not from either legislators or judges.").

14 See generally Blocker v. United States, 288 F.2d 853, 859-62 (D.C. Cir. 1961) (Burger, J., concurring).

A classic and often cited example of psychiatric problems with and manipulations of this phrase is the week-end change in nomenclature at St. Elizabeth's Hospital in Washington, D.C. A staff psychiatrist revealed to the court that between the court sessions on Friday and Monday morning, the hospital officially decided that sociopathic or psychopathic personality disorder was henceforth a mental disease, thus changing the psychiatrists' testimony in the pending case involving such a disorder. See In re Rosenfield, 157 F. Supp. 18 (D.D.C. 1957), described in Blocker, supra at 860 (Burger, J., concurring).

It is important to exclude a possibly serious misunderstanding. Certain current lines of argument purport to establish that mental illness is a myth. See, e.g., SzASZ, THE MYTH of Mental IllNess (1961). These arguments call for a radical reinterpretation of psychiatric theory and of the whole range of abnormal conduct. Such a wholesale thesis is not at issue in the present discussion. The important theoretical problems concerning the foundations of psychiatry and psychology are not directly relevant to the present discussion because the thrust of our analysis is to free the legal tests of insanity from psychiatric controversy.

15 Commtttee on Nomenclature and Statistics of the amerigan Psychiatric Association, Diagnostic and Statistical Manual: Mental Disorders (1952), which used the 
(2) Mental disease is psychosis but not neurosis. ${ }^{16}$ (3) Mental disease is any significant and substantial mental disturbance, or is any condition at all which is authoritatively dealt with by the psychiatrist or physician treating mental conditions. ${ }^{17}$ (4) Mental disease means substantial social maladaptation or incompetence or both as judged by legal criteria. ${ }^{18}$ (5) Mental disease is the failure to realize one's nature, capacities, or true self. ${ }^{19}$

A review of the literature in psychology reveals similar results-there is neither a clear definition of mental disease nor agreement on how best to approach such a definition. ${ }^{20}$

Turning briefly to the legal literature on the question, we again find inconsistency and no help toward providing an appropriate medical definition of mental disease. ${ }^{21}$ In the course of its ground-breaking

phrase "mental disease" in early editions, has explicitly dropped it. "Mental disorder," used as a label for a wide range of conditions which include psychoses, psychoneuroses, and mild personality disorders, is undefined other than by the statement that it is used "generically to designate a group of related psychiatric syndromes," for the purpose of distinguishing the simpler classified conditions from the more complex. "Mental deficiency" is dismissed broadly on the grounds that it is "a legal term, comparable to the term insanity, [which] has little meaning in clinical psychiatry." Id. at 10. See also Hinsie \& CAMpBell, Psychiatric Dictionary 602 (1960) (entry under "psychosis": "It is not considered in keeping with available facts to refer to psychosis as a disease . . . ."); Frohlich, Classification of Mental Disorders, in Encyclopedia of MeNTAL Health 1032 (Deutsch ed. 1963).

16 For testimony of psychiatrists to this effect in the courts, see Lyles v. United States, 254 F.2d 725, 735 (D.C. Cir. 1957); Donnelly, Goldstein \& Schwartz, Criminal Law 758, 769 (1962) (quoting from Record, pp. 225, 380-81, Durham v. United States, 237 F.2d 760 (D.C. Cir. 1956)). See generally Overholser, The Psychiatrist ANd the LAW 26-35 (1953); Hakeem, $A$ Critique of the Psychiatric Approach to Crime and Correction, 23 LAW \& CoNTEMP. Prob. 650 (1958).

17 See, e.g., psychiatrists' reports and testimony in United States v. Currens, 290 F.2d 751, 754-56, 762 (3d Gir. 1961). See generally American Psychiatric Ass'N, A Psychiatric GLOSSARY 47 (2d ed. 1964) ("mental disease" in effect serves as a pragmatic label for a miscellaneous totality of classified conditions at any time, rather than for some specific kind of condition defined with reference to some system of concepts); ENGLISH \& ENGLISH, A Comprehensive Dictionary of Psychological and Psychoanalytical Terms 317 (1958) ("disabling disorder" includes psychosis and neurosis-but turns on social maladjustment); Alexander, Fundamental Concepts, Basic Principles and Assumptions of the Psychodynamic Position on Mental Disease, in Integrating Approaches to Mental Disease 138 (Kruse ed. 1957).

18 See, e.g., ENGLISH \& ENGLish, op. cit. supra note 17, at 317; Group fOR THE AdvaNCEMENT OF PSYchiatry, RePort \#26, 8 (1954); Frohlich, supra note 15, at 1038-39.

19 See, e.g., Goldstein, The Organismic Approach, in 2 ARIetr, AMERICAN HandBook of Psychiatry 1333, 1334-35 (1959); Jahoda, Mental Health, in Encyclopedia of Mental HeALTh 1067 (Deutsch ed. 1963).

20 See generally Scott, Research Definitions of Mental Health and Mental Illness, 55 Psychological Bull. 29 (1958).

21 See, e.g., Hawkins v. United States, 310 F.2d 849 (D.C. Cir. 1962); United States v. Currens, 290 F.2d 751, 771-73 (3d Cir. 1961); Blocker v. United States, 288 F.2d 853, 859.63 
comments on this question, the District of Columbia Court of Appeals has concluded both that mental disease is a medical concept ${ }^{22}$ and that as such it is not restricted to the psychoses. ${ }^{23}$ On the other hand, the Royal Commission on Capital Punishment flatly states that the phrase should explicitly exclude the neuroses and certain other disorders and thus be broadly the equivalent of psychoses. ${ }^{24}$ Pennsylvania, a state whose legislation in this area reflects much recent professional thought, defines mental disease in terms of social maladjustment and legal incompetence. ${ }^{25}$

In summary, while the presence of the "mental disease" element in the criminal law insanity tests would seem to presume the existence of an objective definition, and especially a medical definition, none seems to exist. This is true not only in psychiatry, but also in the nonmedical area of psychology. Thus, despite a series of tacit assumptions that mental disease is a medical concept, the law does not supply any answers and, in granting to psychiatrists broad authority in the guiltfinding process, has tended to defer the responsibility for any definition to the particular psychiatrists in the particular case.

Nevertheless, a definition is important where so central a concept is involved, and one may well wonder whether there may be some objectively identifiable medical condition which ought reasonably to be classified as mental disease on the basis of accepted medical doctrine. It remains possible that the data and the generally accepted doctrine logically allow such a classification even though no one has yet managed to set out the concept in such a manner as to gain general acceptance. To attempt this requires a more analytical and critical approach to the

(D.C. Cir. 1961) (Burger, J., concurring). A general analysis of problems under military law, where "mental disease, defect or derangement" are distinguished from "mere defect of character, will power, or behavior," with particular criticism of Durham, is presented in United States v. Smith, 5 U.S.C.M.A. 314, 320-30 (1954). For general surveys of problems the District of Columbia courts have had under the Durham "mental disease" requirement, see Krash, The Durham Rule and Judicial Administration of the Insanity Defense in the District of Columbia, 70 YALE L.J. 905, 921-29 (1961); Rome, supra note 5, at 106-07. See also Fox, supra note 1, at 666-67.

22 Carter v. United States, 252 F.2d 608, 617 (D.C. Cir. 1957).

23 Briscoe v. United States, 248 F.2d 640, 641 n.2, 644 (D.C. Cir. 1957) ("The assumption that psychosis is a legally sufficient mental disease and that other illnesses are not is erroneous."). See also United States v. Currens, 290 F.2d 751 (3d Cir. 1961) (sociopathic or psychopathic personality not excluded from "mental illness" as matter of law). In Lyles v. United States, 254 F.2d 725 (D.C. Cir. 1957), Judge Bazelon, dissenting, asserted: "Whether psychopathy, generally or of a particular type, constitutes a mental iliness is properly the subject of expert opinion." Id, at 735.

24 The Royal Commission on Capital Punishment, op. cit. supra note 2, at 131.

25 Pennsylvania Mental Health Act of 1951, PA. Stat. ANn. tit. 50, $\S 1072(11)$ (1954). 
problem than can be provided by any mere inventory of dictionaries and authoritative texts.

\section{A Conceptual Analysis of Mental Disease}

The absence of a generally accepted and authoritative definition of mental disease is not an accidental embarrassment of the historical moment but a reflection of the fact that there are no fundamental grounds in medical doctrine for justifying a definition of the term..$^{28}$

Suppose we were to try to discriminate from among all classified mental conditions or disorders those which ought to be set apart as a medically significant group aptly specified as "mental disease." Given the many specific diagnostic categories, what criteria would help to decide which ones in particular are to be classified under mental disease and which not? Or, to put the question in other words, for what purposes would a psychiatrist have to be able to classify a person as having a mental disease or not? The problem is not merely the verbal one of deciding what conditions to term "mental disease." The problem is to find a decisive medical reason for making the decision in one way rather than another.

Let us put the problem more concretely. Suppose, for example, we were to follow the line taken by some of those cited earlier and propose labelling the psychoses and only the psychoses as mental disease. We must ask: What medical reason is there for excluding, for example, the psychoneuroses? To say that the psychoses involve a "break with reality" in a way that the psychoneuroses do not is to present an important psychiatric reason for classifying psychoses and psychoneuroses differently - which is in fact done and is reflected in the use of just those two words. But what additional reason is there for calling one "disease" and

26 The problem is not one of vagueness-a problem ubiquitous in the realms of psychiatric nomenclature. Such a term as "schizophrenia" is distinctly vague, yet it names certain recurring patterns of symptomatology' which are frequently phenomenologically recognizable to the clinician as patterns. Given these patterns, certain typical developments are to be expected, and certain typical techniques are appropriate for handling these developments. That differing diagnoses may be presented by different psychiatrists, that things may not develop as predicted, that treatment may not produce expected results-all of this is acknowledged. Yet, for better or for worse, the practice and theory of psychiatry are formed in terms of this category, among others, and the clinician is at times compelled to use it and to think in terms of it. Thus, vagueness or lack of understanding in connection with a notion does not necessarily exclude it from consideration as a central notion. Although one cannot imagine current psychiatric discussion proceeding without the use of the concept "schizophrenia," however vague the concept, it is easy to imagine psychiatric discussion without use of the phrase "mental disease," and, as noted, this is usually the case. 
the other not? The same reason cannot be given, for the classification "psychosis-psychoneurosis" already takes care of the "break with reality" factor. A consideration of any other medically relevant factor will be found to be expressible in medical terms other than mental disease. In each case the further classification "mental disease" will provide no additional medical information and thus be either empty or redundant. Hence, the use of "mental disease" turns out to occur in a meaningful way only in contexts where nonmedical issues such as those of law, public welfare, social planning, or actuarial analysis are crucial. ${ }^{27}$

Since it is difficult to establish the negative aspect of this proposition, it will be helpful to attempt at this point an indirect analysis of the notion "mental disease." We can most readily commence such an analysis if we turn to an analogy. Then, after analysis of the analogue, we can verify whether the analogue's suggestions concerning mental disease are in fact warranted.

Let us compare the idea of mental disease to the idea of inadequate vision. At first, inadequate vision seems to be a medical concept. Further reflection reveals, however, that although the oculist can provide important and relevant information, he cannot justifiably say, either in purely ophthalmological terms or even in general biological terms, whether vision is adequate. For the oculist's purposes alone, there is no need to define inadequate vision. All he needs to know is to what degree and in what ways a person's vision deviates along a standard scale from some base point on the scale. The oculist also wishes to know about the bodily conditions and sometimes the environmental conditions which make it possible for the person to see or not to see in specific ways. Finally, the oculist would like to know what he can do to induce specific changes. Yet none of this, important as it is, settles the question whether vision is adequate or inadequate.

The question whether vision shall be considered adequate depends on the context and purpose of the use of that vision. Adequate vision for a ditchdigger may not be adequate for a jeweler; and even a jeweler's vision may have such a specific defect as tunnel vision which makes it inadequate for driving a vehicle. The medical condition of the eyes in each case may be the same, but the social task varies. Inadequate vision is thus in part an occupational concept. It is also a concept rooted in public policy. For example, Jones may have adequate vision to drive in a community which is willing to take great risks and which has poor public transportation; whereas he may have inadequate

27 See, e.g., Hall, supra note 5, at 770, 773; Swartz, supra note 4, at 391-93. 
vision in a community where public transportation is excellent and cheap and where public policy favors minimizing risk. In either case the medical condition of Jones is the same.

Given these kinds of grounds for defining inadequate vision in one way or another, the authority to establish the definition is in effect the authority to resolve a policy question, not merely the ability to discover a matter of medical fact. The policy decision calls for an evaluation and synthesis, or at least a compromise, ranging over medical, legal, occupational, and other issues. Neither the oculist nor the traffic engineer alone is competent or authorized to decide the issue, although both can present relevant expert testimony to be used in reaching such a decision. The decision itself must derive from an authoritative interpretation of public policy in the light of the technical information. The definition is in this sense a governmental one, not a medical one.

We are now in a position to formulate more systematically certain logical features of the adoption and use of such a concept.

The grounds for defining the phrase "adequate vision" are the facts of medicine, the technical features of the activity or occupation, the nature of any special context in which the activity occurs, and the relevant public policies. The criteria or tests by which it will be determined whether in fact a person's vision falls under the definition may be purely medical, such as " $20 / 40$ vision minimal, after correction." The grounds for adopting criteria will not wholly coincide with the grounds for adopting the definition. Thus, in adopting criteria, the practicability of administering certain tests will be relevant. The authority for adopting a definition may lie with the legislature or with the governor and may be exercised by establishing a basic motor vehicle code. The authority for adopting criteria, on the other hand, may lie with some person or agency other than the one authorized to adopt a definition, such as the director of the state motor vehicle bureau, after consultation with expert advisors and in conformity with the basic motor vehicle code.

These logical distinctions can help to clarify such questions as whether "mental disease" refers to a medical fact or to subject matter for medical science. For example, when the Royal Commission recommends that "mental disease" should be defined broadly to mean psychosis, ${ }^{28}$ we are likely to suppose "mental disease" is a medical term-if we focus our attention upon the terms of the definition. But if we focus attention on the question of authority, we see that it is

28 The Royal Commission on Capital Punishment, op. cit. supra note 2. But the Royal Commission also offers a much more explicit definition. See note 48 infra. 
broadly speaking the lawmakers who have authority to establish a definition. This suggests what is in fact the case: the grounds for adopting the definition include (indeed are predominantly) matters of public policy, law, and fundamental notions of morality. Since the definition itself is formulated in terms of psychosis, a medical term, it makes sense to adopt medical criteria, and the authority for adopting medical criteria would naturally lie with medical men. If we focus our attention upon the terms of the definition, upon those of the criteria, and upon those persons with authority to adopt criteria (and incidentally to apply them), our impression is powerfully reinforced that this is a medical question with which we deal. Nevertheless, it is crucial for our purposes to realize that the whole affair is initiated for legal purposes, that the definition is authoritatively formulated by lawmakers, and that the fundamental grounds justifying the enterprise are largely nonmedical.

There are many different nonmedical or not entirely medical contexts in which we may seize upon the phrase "mental disease" as a handy device for accomplishing our purposes. For example, if we wish to withdraw certain groups, such as addicts, homosexuals, and alcoholics, from the punitive approach of the law, we may so use the phrase "mental disease" as to include these groups among the mentally diseased. The phrase may also be used to refer to those persons for whom public care or treatment is thought desirable. Physicians, on the other hand, may use the phrase to emphasize to the layman that a certain person needs or might profit from psychiatric care. For actuarial purposes, the phrase may be useful to single out groups which have a relatively high incidence of occupational or other insurable disability without discoverable organic basis. In all these cases, the language itself ("disease") and the fact that the criteria are so largely formulated in medical terms give the impression that this is a medical question per se. But in each case the grounds for the definition (and often the criteria) and the authority for adopting the definition are largely nonmedical. From this latter perspective, "mental disease" is not a medical term, but a moral, legal, or actuarial one. In each case the phrase "mental disease" is a term used to introduce various nonmedical issues into a context where medical expertise is expected to be a "high-visibility" source of aid.

In the criminal law, in particular, the treatment of the problem of mental disease has been confused by the failure of the courts to distinguish between the grounds for introducing the phrase, the definition itself, the grounds for adopting criteria, the formulation of the criteria, and the authority for adopting a certain definition or certain criteria. The courts have failed to appreciate that while medical tes- 
timony often is relevant to the application of courtroom criteria of mental disease, the grounds for the (tacit) definition, the grounds for adopting the criteria, and the authority behind the whole are largely legal and moral, not medical.

The District of Columbia cases which have followed Durham $v$. United States" and which have attempted to apply the "product of mental disease or mental defect" requirement enunciated in that case are particularly relevant in showing this confusion. In Durham the court elaborated on its basic formulation only to the extent of distinguishing between "disease" and "defect" in that the former term was used "in the sense of a condition which is considered capable of either improving or deteriorating," whereas the latter was a nonchanging condition "which may be either congenital, or the result of injury, or the residual effect of a physical or mental disease." 30 In effect, the terminology employed in this definition is medical, but it is also quite vague. If it were intended to provide any guidelines at all, even to experts before the court, it certainly never achieved that purpose. ${ }^{31}$

In Carter $v$. United States, ${ }^{32}$ the appellant's conviction for first degree murder was reversed and the case remanded for a new trial. The court found numerous errors in the trial court proceeding and discussed the insanity test only for purposes of guidance in the second trial. The court stated:

Mental "disease" means mental illness. Mental illnesses are of many sorts and have many characteristics. They, like physical illnesses, are the subject matter of medical science.... The problems of the law in these cases are whether a person who has committed a specific criminal act-murder, assault, arson, or what not-was suffering from a mental disease, that is, from a medically recognized illness of the mind . . . . ${ }^{33}$

While the court was careful to indicate that the testimony of psychiatrists is only one form of evidence and that the ultimate determinations and inferences are for the trier of fact, there is an underlying assumption not only that medicine properly has authority, that it can define mental disease, but also that it has in fact exercised this authority. And implicit in these suppositions is a further presupposition: the court tacitly assumes that the grounds upon which a par-

29214 F.2d 862 (D.C. Cir. 1954).

$30 \mathrm{Id}$. at 875. See generally Wechsler, The Criteria of Criminal Responsibility, $22 \mathrm{U}$.

CHr. L. REv. 367 (1955).

31 See, e.g., McDonald v. United States, 312 F.2d 847 (D.C. Cir. 1962).

32252 F.2d 608 (D.C. Cir. 1957).

33 Id. at 617. (Emphasis added.) 
ticular definition would be adopted are substantially medical grounds - for if there were relevant and important nonmedical considerations involved we should hardly expect the medical specialist alone to be qualified to decide upon a definition.

Since the law insists on "mental disease" as a central term but gives no clue as to its meaning except to say that it is a medical term, many psychiatrists, desirous of cooperating responsibly with the law, have felt compelled to decide the meaning of mental disease. Predictably, the course of reaching such decisions has required the psychiatrists to anticipate what the court will accept as a definition to excuse from criminal responsibility. As a result, psychiatrists have made a pragmatic judgment that the courts will not accept every disorder as a disease $^{34}$ and a conscious attempt to utilize a psychiatric category which they suppose will roughly serve-at least serve better than any other single psychiatric category-to bring out the mental conditions relevant to criminal responsibility. Thus, the general tendency of the psychiatrists under both Durham and M'Naghten has been to equate mental disease with psychoses. ${ }^{35}$ Of course, in so doing the psychiatrist is making a judgment about criminal responsibility-a judgment which he explicitly is not authorized to make and with respect to which he is of course not expert. ${ }^{36}$ In effect, the courts have thus given the medical men a blank check in matters of vital importance to the court.

In 1962, the District of Columbia Circuit, in McDonald v. United States, ${ }^{37}$ reversed and remanded the appellant's lower court conviction for manslaughter, apparently because the trial judge did not properly instruct the jury on the meaning of the insanity defense. ${ }^{38}$ However, the court also set out in its opinion a judicial definition of mental disease $^{39}$ and thus seems to have appreciated that in some way its

34 See, e.g., Donnelly, Goldstein \& Schwartz, op. cit. supra note 16, at 782 (quoting from Record, Lyles v. United States, 254 F.2d 725 (D.C. Cir. 1957)).

35 See generally Hall, supra note 5, at 784-85; Reid, The Working of the New Hampshire Doctrine of Criminal Insanity, 15 U. Muam L. Rev. 14 (1960). See also Donneluy, GoldsteIn \& SchwarTz, op. cit. supra note 16, at 758, 769 (quoting from Record, Durham v. United States, 237 F.2d 760 (D.C. Cir. 1956)).

36 See Rubin, op. cit. supra note 4, at 81; Reid, supra note 35, at 15-16; Szasz, supra note 12 , at 189 .

37312 F.2d 847 (D.G. Gir. 1962).

38 See discussion by Miller, J., dissenting and concurring. $I d$. at 852.

39 " $[\mathrm{T}]$ he court does take [in the majority opinion] two important, much needed and long overdue steps: (a) it says, for the first time, what we mean by the term 'mental disease or defect' in connection with criminal responsibility; (b) it rules quite clearly that the jury is the sole and final judge of the credibility of all witnesses, including those who testify as experts, and that it is to be so instructed. Heretofore, these two elements have been sadly lacking in this court's opinions." Id. at 861 . 
previous use of this term was not simply "the" medical use and that it could not leave the issue of mental disease to the medical men.40 Although the court referred to a "clinical" use, it asserted that "a 'mental disease or defect' for clinical purposes ... may or may not be the same as mental disease or defect for the jury's purpose in determining criminal responsibility." 41 At last, the focus is not on psychoses or other broad psychiatric categories, ${ }^{42}$ but on "mental disease," a phrase recognized as requiring "a judicial definition, however broad and general, of what is included in the terms 'disease' and 'defect.' "43 The definition proposed was relatively simple and concise:

$[F]$ or the jury's purpose in determining criminal responsibility ... [it] should be told that a mental disease or defect includes any abnormal condition of the mind which substantially affects mental or emotional processes and substantially impairs behavior controls. ${ }^{44}$

This definition of mental disease reverts to the logical form of the M'Naghten test of insanity; it telescopes into the one term, "mental disease," the several variables, in their original logical relationships, of the entire M'Naghten formula. ${ }^{45}$ In the $M c D o n a l d$ definition and also in M'Naghten, a general or underlying condition is first mentioned: in McDonald it is "an abnormal condition of the mind," and in M'Naghten it is "disease of the mind." In both cases this condition is the source or cause of more specific mental debilities bearing on criminal responsibility. In McDonald the abnormal mental condition "substantially affects mental and emotional processes and substantially impairs behavior controls," whereas in M'Naghten it is "from" disease of the mind that there arises a "defect of reason" consisting in a failure to know the nature of the act or its moral quality. In the expanded

40 In this connection, see subsequent explanations of McDonald in Gray v. United States, 319 F.2d 725, 727-28 (D.C. Cir. 1963) (Burger, J., concurring); Hawkins v. United States, 310 F.2d 849, 851-52 (D.C. Cir. 1962).

41312 F.2d at 851 . Perhaps the court even appreciated that there is no systematic medical use, for it also referred to "ad hoc definitions or conclusions as to what experts state is a disease or defect." Ibid.

42 See The Royal Commission on Capital Punishment, op. cit. supra note 2. Cf. Carter v. United States, 252 F.2d 608, 617 (D.C. Cir. 1957), where the court, after generally stating that mental disease is properly the subject matter of medical science, notes that "unexplained medical labels - schizophrenia, paranoia, psychosis, neurosis, psychopathy-are not enough. Description and explanation of the origin, development and manifestations of the alleged disease are the chief functions of the expert witness."

43 312 F.2d at 850-51.

44 Id. at 851 .

45 See note 7 supra. 
versions of the M'Naghten test allowed in some jurisdictions, a defect of the will ("irresistible impulse") is an additional item which may serve as the debility arising "from" disease of the mind. The main difference between McDonald and M'Naghten is that in both of its parts $M c D o n a l d$ is in crucial respects more sweeping and more vague. It is also fundamentally question begging in a way in which M'Naghten is not.

Under the McDonald definition the trier of fact who finds the mental and emotional processes "substantially impaired" must still ask: "affected" and "impaired" in what way? ${ }^{46}$ The obvious answer is: affected and impaired in a way which results from an "abnormal condition of the mind." But surely not just any abnormality of mind will do for the present purpose. A person who is in a state of self-induced alcoholic or narcotic intoxication is in an abnormal condition of the mind which can often substantially affect intellectual and emotional processes and impair behavior controls. Again, unavoidable or negligently induced extreme fatigue and exhaustion is associated with an abnormal condition of mind which may substantially affect intellect and emotion and impair behavior control. But surely these kinds of abnormal conditions of the mind are not appropriate for the purpose of excusing from criminal responsibility by reason of insanity.

What is clearly needed is a statement of that specific sort of mental abnormality which will help to establish the insanity plea. What kind of abnormal mental condition must the court have tacitly had in mind when it formulated the definition? One possible answer is the specific form of mental abnormality whose presence, appropriately connected to the act, excuses from criminal responsibility. But this answer is obviously defective on two grounds: (a) it makes the whole test a question begging one since the mental disease test is supposed to provide an independent criterion of the absence of criminal responsibility; (b) it is still too general, for it is not difficult to think of mental abnormalities whose presence, when appropriately connected to the act, typically do excuse from criminal responsibility but which do not provide the basis for an insanity plea. Such a condition would be produced, for example, by nonnegligently induced exhaustion. Another possible answer would restrict the insanity plea to those mental abnormalities which exist in involuntarily induced disorders in order to exclude mental abnormalities produced by exhaustion, intoxication, concussion, and

46 The problems of vagueness relating to use of the term "substantially" are omitted here as irrelevant. For discussion of these problems in connection with the Model Penal Code insanity test, see GruecK, op. cit. supra note 4, at 22-23. 
the like. But this also renders the McDonald definition hopelessly question begging. The point of using the phrase "abnormal condition of the mind" was precisely to help define what the court meant by "mental disease."

Thus, the court in McDonald recognizes the inadequacy of treating mental disease as a medical concept and proposes that since this concept serves specific legal purposes it should be defined accordingly. ${ }^{47}$ However, the opinion fails to build on a constructive account of that legal role and thereby offers a definition which compounds the present confusion. ${ }^{48}$

47 See, e.g., Blocker v. United States, 288 F.2d 853, 859-62 (D.C. Cir. 1961) (Burger, J., concurring). McDonald has not been universally acclaimed, however, at least not in the context of the Durham rule. The criticism can be resolved into the basic observation that the jury is concerned with blame and responsibility, that the whole posing of the question in terms of disease is wrong. See generally RuBrN, op. cit. supra note 4, at 52-62.

48 There have been two other prominent legal attempts to provide a definition for mental disease in recent years. The Pennsylvania Mental Health Act of 1951 provides:

"Mental illness" shall mean an illness which so lessens the capacity of a person to use his customary self-control, judgment and discretion in the conduct of his affairs and social relations as to make it necessary or advisable for him to be under care. The term shall include "insanity," "unsoundness of mind," "lunacy," "mental disease," "mental disorder," and all other types of mental cases, but the term shall not include "mental deficiency," "epilepsy," "inebriety," or "senility," unless mental illness is superimposed. PA. Stat. ANN. tit. 50, § 1072(11) (1954).

Of course this definition is formulated for purposes of civil committability and is broader than "Iegal insanity." See Commonwealth v. Moon, $383 \mathrm{~Pa} .18,27,117$ A.2d 96, 101 (1955). Pennsylvania, while adhering to M'Naghten for purposes of assessing criminal responsibility, see Commonwealth v. Novak, 395 Pa. 199, 150 A.2d 102 (1959), has applied the Mental Health Act definition in determining whether a convicted murderer should be committed for care, noting that the standard as to mental capacity of a defendant to stand trial or be sentenced differs from that as to responsibility ("legal insanity"). See Commonwealth v. Moon, supra at 23, 117 A.2d at 99.

A second effort to define "mental disease" may be found in The Royal Commission on Capital Punishment, op. cit. supra note 2, at 73: "By 'mental disease' or 'disease of the mind,' we mean a pathological change arising de nowo in the mind of an individual who has already progressed some way towards maturity or has attained it. We recognize that mental disease may occur in children, adolescents or adults, in persons of retarded or of normal intelligence, and in persons of normal or of psychopathic temperament. We conceive, however, that the implications of the word 'disease' are that a new element of mental deterioration or disorganization is introduced, bringing with it a qualitative departure from the previously established norm. For us, therefore, mental disease is only one part of mental disorders of all kinds, and broadly corresponds to what are often called major diseases of the mind, or psychoses; although it may also arise in cases such as those of epilepsy or cerebral tumor, which are not ordinarily regarded by doctors as psychotic."

It is to be noted, however, that this definition is largely cast in medical terms. Moreover, by its attempted differentiation between major and minor diseases of the mind-psychoses as opposed to psychopathic personality, neurasthenia, and so forth-the Commission indicates that it is really not providing a systematically grounded definition of mental disease at all, but only providing convenient terms for use by the forensic psychiatrist. 


\section{The Constructive Role of Mental Disease}

Since M'Naghten the decisions of the English and American courts as to criminal insanity have revolved around two key elements: (1) the current, responsibility-impairing mental debility out of which came the act, ${ }^{49}$ and (2) the source out of which came the mental debility"mental disease" in the tests in use since M'Naghten. ${ }^{50}$ The first of these elements comprises the main part of the M'Naghten test-the inability to know the nature or wrongness of the act-and can be traced in the legal writings for centuries prior to M'Naghten. ${ }^{51}$ However, the concept "disease of the mind" first emerges authoritatively in M'Naghten, although the search for an explanation as to the cause of the lack of understanding of the insane person had also been pursued over several centuries. ${ }^{52}$

By using "disease of the mind" M'Naghten accepts implicitly the

49 The notion of "current, responsibility-impairing mental debility" has been coined to express the general concept appearing in all of the insanity tests (except Durham in its pre-McDonald form) of an inability to know, to control, or to conform at the time of the criminal act. In M'Naghten, for example, this condition is stated as a "defect of reason ... as not to know the nature and quality of the act he was doing; or, if he did know it, that he did not know he was doing what was wrong." $10 \mathrm{Cl}$. \& $\mathrm{F}$. at 210, 8 Eng. Rep. at 722. This current debility is characterized in terms of everyday moral psychology"reason," "know," "conform," "impulse," "appreciate," "defect," "incapacity." In each case this debility is specific to the prohibited act, i.e., it "causes," "produces," or is a necessary condition of the act's occurrence. In each case this debility is in turn designated as being "from" or "the product of" mental disease. The mental debility is what has the immediate morally vitiating effect upon the act, i.e., it establishes defect or peculiarity in the responsibility status of the act. The source (mental disease) element is necessary to specify one particular form of such defect in responsibility-insanity.

50 Durham originally dropped the current mental debility element as being unduly limiting, causing criminal responsibility "to rest upon [one] particular symptom." 214 F.2d at 872. However, McDonald in effect reintroduced this element through its broad definition of mental disease. See text accompanying note 45 supra. Thus, both elements -current mental debility and mental disease-may be found in all the current insanity tests.

51 See generally United States v. Currens, 290 F.2d 751, 769-65 (3d Gir. 1961); GLuECK, Mental Disorder and the Criminai. Law 123-60 (1925).

52 The element of mental debility was used by Hale and Tracey, who agreed that it consisted of not understanding or knowing what one was doing. The insane person was considered a mental child. See generally Crotty, The History of Insanity as a Defense to Crime in English Criminal Law, 12 CALIF. L. REv. 105 (1924). However, the source of this debility was variously framed in terms of the Aristotelian "humours" or of the newer Lockean "faculty psychology" arising out of the scientific-materialistic upsurge in the late seventeenth century. M'Naghten abandons "humours," but retains Lockean faculty psychology in its use of "defect of reason." "Humours" are replaced by "disease of the mind," reflecting the great eighteenth and nineteenth century upsurge in scientific interest in anatomy and disease causation and prevention. The Benthamite concern for a rational approach to social and bodily ills and the new emphasis on and reliability of diagnosis as leading to cure are certainly relevant in this change. See generally SINGER \& UNDERWOOD, A SHORT History OF MEDICINe 208-36, 244-80 (1962). 
analogy between physical diseases, in which a number of cases could be identified and treated rationally, and mental disease, where nothing so specific was then possible. ${ }^{53}$ "Disease" offers a serviceable analogy for use in the context of criminal responsibility because it is possible to view some criminal-like conduct as morally similar to the symptom of a disease. The ordinary physical disease symptom is an abnormality which is produced from within the person himself; it is the result of something in the person, or of something about the person's makeup which is at least for the time a part of him. Yet, although it exists within the person and may be said to be produced by him, it is produced involuntarily. Not only is the symptom produced involuntarily, but the condition which produces it, the disease, is itself present independently of the person's will at the time. The symptom of a physical disease is thus said to "happen" to the person-a formulation with a profoundly important moral point bearing on the issue of responsibility. ${ }^{54}$ The requirement that the current mental debility of the person be "from" disease of the mind was thus a crucial limiting condition. The mental debility element in the formula singles out a specific, effective mental derangement which vitiates the immediate moral or legal integrity of the act. The mental disease element of the formula tells us something morally and legally relevant about how this debility came about. The mental debility came about as the result of something deeper from which the person suffers. ${ }^{55}$

In applying the insanity test, the trier of fact begins by asking whether the prohibited act resulted from mental debility. If it is proven beyond a reasonable doubt that the act did not result from such debility, ${ }^{56}$ the insanity plea is refuted. However, if this is not proven,

53 M'Naghten is thus an explicit step in the direction of the scientific materialism which was intellectually fashionable in the nineteenth century. At the time, the analogy rested only on a hope-one in which the educated man supposed that a major portion of mankind's troubles could be diagnosed under the heading "disease" and that it was in terms of the new knowledge of the body, and of the brain, that these troubles would soon be medically curable.

54 The older concepts of "humour" and "faculty psychology" were employed to reach substantially the same interpretation and evaluation-that the current mental debility leading to the act was produced from within the person, from something a part of him, but independently of his will.

55 See, e.g., Roche, The Cruminal Mind 14-29 (1958).

50 There are certain requirements relating to the burden of proof and burden of persuasion that are of course relevant to this determination. These may vary somewhat as to insanity from one jurisdiction to the next, but may be generally stated as follows. There is first an assumption that all persons are sane. The defense, by raising the issue of insanity in a substantial manner (by "some evidence" in the District of Columbia, Briscoe v. United States, 248 F.2d 640, 643 (D.C. Cir. 1957)), then imposes on the prosecution the burden of proving this issue (sanity), as all others relating to the alleged crime, beyond a reasonable doubt. See generally Krash, supra note 21, at 934-37. 
the trier of fact next asks: Did this current mental debility have its source in mental disease (or defect) ${ }^{57}$

This latter question may be explicated in three alternative ways: (1) Did the mental debility have as its source a condition or feature of the person's own makeup, a condition suffered involuntarily? (2) Did the mental debility have its source in a condition which, however or wherever initially produced, at the time of the prohibited act had an existence relatively independent of external causes, of foreign substances incorporated into the body, or of intentional acts or negligence by the person himself? (3) Was the mental debility the specific effect, relatively limited in time, of some particular external circumstance, or external occurrence, or foreign substance incorporated into his body? If it is proven beyond reasonable doubt that (1) or (2) are answered negatively, or that (3) is answered affirmatively, then the plea of insanity is refuted. Otherwise, the defendant must be held not guilty by reason of insanity.

As the court in McDonald $v$. United States ${ }^{58}$ stressed, the psychiatrist's role in the criminal insanity trial becomes that of an expert testifying to his observations in terms of symptoms, how these related to the person's makeup, the possible mental state at the time of the act in question, and how the mental state related to the act.59 Medical terms may be employed, but should be clearly explained to the jury in terms of probable conduct or behavior of the person. The expert would not be compelled to answer the question, "Did the defendant have a mental disease?" The triers of fact would have to answer the question: Did the defendant's act arise out of a (morally vitiating) mental debility (as specified in the particular rule used by the court), and was this debility rooted in the person's own makeup, not merely as a local effect of something which has happened or been

57 Although the exact terminology which should be used to single out this issue is debatable, "mental disease" would probably remain the best choice because of the weight of precedent. Perhaps "disease" is too insistently medical in its overtones and suggests too strongly a condition of limited duration. Perhaps "disorder" or "abnormality" would better serve to deemphasize the narrower medical interpretation as well as the suggestion of a limited duration. It would appear, however, that this is only a matter of detail in the tactics of creating a legal language, and therefore "mental disease or defect" should be retained.

58312 F.2d 847 (D.C. Cir. 1962).

59 There are obvious problems of causation here. Much of the criticism of Durham -originally grew out of the formulation of a "product" test. See, e.g., Reid, supra note 35, at 30-31; Wechsler, supra note 30, at 369-72. The District of Columbia Circuit has dealt with this problem specifically on a number of occasions since Durham. See, e.g., Campbell v. United States, 307 F.2d 597, 601-02 (D.C. Cir. 1962); Carter v. United States, 252 F.2d 608, 615-17 (D.C. Cir. 1957); Douglas v. United States, 239 F.2d 52, 57-59 (D.C. Cir. 1956). 
done, but as something which was involuntarily a part of him? No psychiatric label could settle the issue; no psychiatrist need feel obligated to offer an expert medical opinion on such a question, for it is not a scientific question. ${ }^{60}$ In all its key concepts it is a moral-legalpractical one. ${ }^{61}$

The principal problem of a definition of mental disease along these lines is that it inherently leaves a certain vagueness with respect to how the condition which is the source of the mental debility is to be identified from among all the other concurrent and contributing conditions. Nor is it always clear how to determine when a condition exists independently of local and limited causes and is instead suffered involuntarily as a feature of the person's makeup. We do not have and cannot have unambiguous or precise criteria for assigning causality, nor can we have them for defining what is involuntary or what is part of a person's makeup. For although the notions of a critical cause, of the voluntary, and of what makes up the person are vital and necessary notions of everyday moral psychology and of law, they are not precise notions; they have a core of obvious meaning, and there is a wide periphery where we must decide what to say in the particular case.

The existence of these problems, however, does not justify abandoning the kind of definition of mental disease here proposed. The sorts of questions I have posed express necessary elements of the very meaning of the doctrine that a person may justly be held not guilty of a criminal act by reason of insanity. Since that doctrine is not only well-rooted in precedent but justly reflects an important social, moral, and legal distinction, we must try to answer the questions it poses. The vagueness inherent in the notion of mental disease, like the vagueness of reasonable doubt, probable cause, ordinarily prudent man, and other such notions, is a vagueness which genuinely belongs to certain crucial and proper notions in law.

Furthermore, the attempts to avoid such problems have led to the adoption of spuriously precise and spuriously unambiguous proposals. The practical confusion that the "mental disease is a medical fact" approach, for example, has generated is well known; I have discussed the theoretical confusion at length. The law would do well to avoid

B0 It should be noted that one of the aims of the Durham test was to avoid asking the psychiatrist questions demanding a yes or no answer, answers which from his background, training, and investigation he could not properly supply. See, e.g., Carter v. United States, 252 F.2d 608, 617 (D.C. Cir. 1957); Guttmacher, The Psychiatrist as an Expert Witness, 22 U. CHr. L. REv. 325 (1955). Under the guise of mental disease, however, a similar unanswerable question has continued to be posed.

61 Which is to say, it is a question relating to the everyday moral psychology considered within the reach of a juror's experience and knowledge. 
substituting the wrong question for the right one because the former is more clear or is thought on its face to be so. The task of the law is to accept the burden of deciding legitimate, albeit vague, questions. The question of mental disease can be formulated with the authority of law, on legal grounds, in the language of law and everyday moral psychology, and with respect to a genuine and important class of cases in criminal law. 